\title{
Antigone's Line
}

\author{
Mary Beth Mader
}

"Leader: What is your lineage, stranger? Tell us-who was your father? Oedipus: God help me! Dear girl, what must I suffer now? Antigone: Say it. You're driven right to the edge."

Sophocles' Antigone has elicited many superlatives. Hölderlin considered the play to be the most difficult, the most enigmatic and the most essentially Greek of plays. This paper treats a matter of enigma in the play, one that is crucial to understanding the central stakes of the drama. Its main purpose is to propose a novel account of this enigma and briefly to contrast this account with two other readings of the play.

One passage in particular has prompted the view that the play is extremely enigmatic; it is a passage that has been read with astonishment by many commentators and taken to demand explanation. This is Antigone's defense speech at lines 905-914. Here, she famously provides what appear to her to be reasons for her burying her brother Polynices against the explicit command of her king and uncle, Creon. Her claim is that she would not have deliberately violated Creon's command, would not have intentionally broken his law or edict, had this edict barred her from burying a child or a husband of hers. She states that if her husband or child had died "there might have been another." But since both her 


\section{ANTIGONE'S LINE}

mother and father are dead, she reasons, "no brother could ever spring to light again."2 Reasoning of this sort has a precedent in a tale found in Herodotus' Histories, and Aristotle cites it in Rhetoric as an example of giving an explanation for something that one's auditors may at first find incredible. ${ }^{3}$ To Aristotle, then, Antigone's defense speech appears to have been "rhetorically satisfactory," as Bernard Knox says. ${ }^{4}$ However, such a reception is rare among commentators. $^{5}$

\section{Dramatic Implausibility}

Indeed, commentators including Goethe and Lacan have considered this supposed reasoning a scandal and something closer to non-reasoning, something nearly inhuman. Goethe hoped that one day the passage would be shown to be interpolated. ${ }^{\circ}$ Therese Ahern Augst ${ }^{7}$ writes that Antigone's valuing this particular brother uniquely means that she "approaches the limit of what is commonly understood to be human nature." Others, like Bernard Knox, find Antigone's thinking both distressing and contradictory. Knox argues that in this speech Antigone abandons the justification she had put forth throughout the play, namely, that of the priority of blood-relations, especially over state commands or the laws of mortals or men. ${ }^{8} \mathrm{He}$ alleges that:

her assertion that she would not have done for her children what she has done for Polynices is a spectacular betrayal of that fanatical loyalty to blood relationship which she urged on Ismene and defended against Creon, for there is no closer relationship imaginable than that between the mother and the children of her own body. ${ }^{9}$

It is, he argues, a "strange piece of reasoning" that Antigone marshals to justify the "disturbing statement" that she would not have committed her lawbreaking deed for a husband or child of hers. Knox realizes that the defense involves the irreplaceability of Polynices. But his reading does not see that questions which are the motor of the dramatic course and tragic problems of the play itself, and the answers to which he takes for granted, are precisely what are either unanswered or in play in the dramatic action of the work. 


\section{MARY BETH MADER}

\section{Attempted Solutions: “But You're in Love with Impossibility"10}

Knox interprets Antigone's true motive as betraying a general principle of devotion to blood relations. He holds that though she begins by defending herself in universal terms, with such claims as "Hades longs for the same rites for all,"11 she ultimately demonstrates that this is not the genuine motive for her prioritizing of her brother over a hypothetical husband or child in the defense speech. He finds that in the end:

the driving force behind her action, the private, irrational imperative which was at the root of her championship of the rights of family and the dead against the demands of the state...is her fanatical devotion to one particular family, her own, the doomed, incestuous, accursed house of Oedipus and especially to its most unfortunate member, the brother whose corpse lay exposed to the birds and dogs. ${ }^{12}$

How does this relate to her championing of the divine law, for Knox? He argues that this "purely personal" motive of devotion to her own family is the "determinant" for her allegiance to the divine law. He identifies Antigone as an instance of a Sophoclean hero whose determined actions and unyielding character are those of "human beings who refuse to recognize the limits imposed on the individual will by men and gods, and go to death or triumph, magnificently defiant to the last." 13

Others have regarded the passage as turning on a question of love, as either a rejection of the erotic, as in Martha Nussbaum's assessment, or as the incoherence of extreme passion, as in Elizabeth Wyckoff's account. Nussbaum writes:

The best explanation for this coldly determined priorityordering of duties is that Antigone is not animated by personal love at all, but by a stern determination to have a fixed set of ordered requirements that will dictate her actions without engendering conflict; her refusal of the erotic...is then sufficient to explain her choice of the brother.... ${ }^{14}$

And Wyckoff offers the view that Antigone is "clinging to her irrational profundity of feeling for her lost and irreplaceable brother, 


\section{ANTIGONE'S LINE}

devising legalistic arguments for her intellectual justification."15

These, then, are a few of the many reasons for which readers of the play have found this passage confounding, and several of the ways that they have sought to account for its oddity. Before a sketch of this paper's proposed understanding of the enigma of the passage, a brief presentation of two inventive and important interpretations of the play follows: those of Jacques Lacan and Judith Butler. Each of these thinkers mines Sophocles' drama with relentless care for its philosophical yield. In order to clarify the details of this paper's reading, their interpretations will be contrasted to it. The comparison focuses on the readings of the enigmatic passage at issue and points related specifically to it.

\section{Jacques Lacan: The Tautology of Human Being}

In 'L'Essence de la tragédie: un commentaire de l'Antigone de Sophocle,"16 Jacques Lacan discusses Goethe's perplexity at Antigone's scandalous ranking of her brother over an eventual husband or child. Though Goethe's shock at the passage includes the wish that it one day be shown not to have been part of the original text, Lacan judges this hope unlikely; if it had been known to be so scandalous why would Aristotle have cited the passage despite that fact a mere eighty or so years after its composition? One of Lacan's many aims in the essay is to make sense of this apparently implausible passage.

According to Lacan, Antigone's elevation of her brother, her willingness-and will-to die for revering him, stems from her insistence on his very being, stripped of any of the contingencies of his individual history. This being, unadorned by a past of action, by inherited particularities-not caught in a knotted line of descent, or murderously counterpoised to a brother-is conceivable only thanks to the advent of language, for Lacan. For her part, Antigone cites "the great unwritten, unshakeable traditions....these laws;" 17 if she disobeys Creon's royal command, it is to obey another law, and only to obey it. ${ }^{18}$ Lacan argues that legality itself is of the structure of language, and that even if Antigone's cherished laws are "unwritten," their nomological quality itself is conceivable only on the basis of the essence of language. The unique value of the brother's bare being, shorn of its lifetime of qualifiers, is a function of the individuating and reifying powers of signification. It is signification alone that permits the ontological isolation of the being of a being, abstracting it both from a Heraclitean 


\section{MARY BETH MADER}

flow of change and from its own causal history. Language freezes the frame on what passes(,) as undifferentiated. In doing so, it reveals that which perdures in its tautological quiddity: it is what it is. ${ }^{19}$ Lacan explains:

My brother is what he is, and it is because he is what he is, and because only he could be that, that I proceed towards this fatal limit. If it were any one else whosoever with whom I could have a human relation, my husband, my children, they are replaceable, they are relations, but this brother who is $\alpha \theta \alpha \pi \tau 0 \zeta$, who has this thing in common with me of being born of the same womb-the etymology of $\alpha \delta \varepsilon \lambda \varphi o \zeta$ alludes to the womb - and of being tied to the same father, the criminal father whose criminal aftereffects Antigone is trying to cleanse-this brother is something unique, and it is this alone that moves me to oppose your edicts. $(278-279)^{20}$

The brother's value is held to be that of a unique being, the being named by a proper name. In fact, contrasting the human being with a dog, Lacan proposes that the text implies that the burial requirement itself flows from the nature of the being endowed with a proper name: "One cannot do away with his remains while forgetting that the register of the being of he who has been able to be situated by means of a name must be preserved by the act of the funeral." But at the same time, Lacan holds that Polynices is uniquely valuable because he shares a feature with Antigone, namely, being born of the same womb.

Though Lacan's account does not represent an entirely coherent interpretation, it is consistent in suggesting that uniqueness, and unique value, flow from signification. The proper name permits the ontological excision from the indistinction of constant change and the determination of any individual identity over time. But it would seem that Lacan's demonstration extends too broadly for it to be of specific use in his present argument. If true, it would be true of all of those other beings - husband, child, anyone (not born of the same womb?) — that the explanation is supposed to exclude from its scope.

The crux of Lacan's position with respect to the enigmatic passage is that there is a signifying void at the heart of Antigone's justification. This void is the radical break and the atemporality that paradoxically is inaugurated-that is, it occurs at a time-with the advent of the linguistic function of detaching pure being from... everything else. 


\section{ANTIGONE'S LINE}

Lacan writes that: "this purity, this separation of the being from all the characteristics of the historical drama it has gone through, this exactly is the limit, the ex nibilo about which Antigone takes place" (279). ${ }^{21}$

But perhaps Lacan is too hasty here. How does the brother's uniqueness stem both from "being born of the same womb" and from being radically detached from his "historic drama?" Is not "being born of the same womb" part of his "historic drama?" How "detached" from his history can he be if his very birth itself is consequential, that is, if his birth entails his uniqueness, or his uniqueness to Antigone? Is his birth prior to his history, displaced backwards into an untimed, unthought, imagined zone so that he can exist purely, an ahistorically unique being?

One way of squaring Lacan's claims is to consider that Polynices is unique because he is born of the same womb, as would be anyone who is also born of the same womb. This comes closer to expressing the heart of Antigone's thinking, in my view, but what remains to be investigated here is why Antigone might be particularly concerned with this. I hope to provide an answer to this question below.

In the meantime, it would be helpful to note that when Lacan enumerates those for whom Antigone would allegedly not violate the royal prohibition, he writes "any one else whosoever with whom I could have a human relation, my husband, my children, they are replaceable, they are relations...." Yet this is a misleading characterization of Antigone's thought. In fact, she does not say that she would not break Creon's law for anyone else except her brother, or for anyone else except a brother, or, for that matter, for anyone else except someone "born of the same womb." She just says she would not break the royal edict for a dead husband or child. This is not the same as claiming she would do it for no one else besides her brother, or a brother or a sibling. Incidentally, she also does not say that she would not bury anyone else. She says she would not break the law to bury a husband or child.

Certainly, Antigone grants her invading brother a special status, even one that is special because he is born "of the same womb." The question raised by the enigmatic passage, though, is a comparative one: why rank the brother over husband and child (and not, as Lacan implies, over anyone besides Polynices)? Why not consider all philous, that is, all "“friends and "close relations,",22 as equally worthy of risking death by violation of a royal decree prohibiting their burial? After all, why would husband or child not likewise each be what each is, and each likewise 


\section{MARY BETH MADER}

be considerable and unique in his or her very being itself? If Lacan means that it is in his role as brother that Polynices is what he is, then husband or child could likewise each be what each is in his or her role as husband or child.

Moreover, it is not simply that the brother is irreplaceable and an eventual husband or child is replaceable. As I hope to show below, there are two issues of replaceability: one is the issue of replaceability per se, the other is the issue of replaceability by Antigone, that is, by her own effort or agency. Commentators have overlooked this second issue though its importance for the passage in question is great.

If the first sort of replaceability were solely what was at issue, this would imply that Polynices would obtain his unique comparative value solely upon the death or infertility of his parents. For prior to either of those, he would be replaceable precisely in the sense that his parents could generate another son (assuming they could). That is, he would be replaceable in the very sense that Antigone proclaims her own future child to be; she could have another (child). Of course, it is odd to think that Antigone is dying to consecrate the special value of her brother as it emerged suddenly upon the death of her parents! We have reason to suspect that something else is operating to account for her reasoning.

\section{Judith Butler: Normative Repetition and Radical Singularity}

There is not the space here to address in detail the far-ranging philosophical analysis offered in Antigone's Claim, ${ }^{23}$ Judith Butler's probing inquiry into Sophocles' Antigone. The ultra-welcome critiques of Hegel and Lacan, the urgently clear questioning of a whole history of anthropological, feminist, and psychoanalytic thought on kinship, and the vitally topical formulations of conceptual problems confronting research on the philosophical issues that attend new, or apparently new, family forms and modes of kinship all light the way in particularly forbidding territory. They are equally courageous, politically stimulating, and insightful.

Butler is especially helpful in pointing out Antigone's profound kinship confusion, and the difficulty of locating Antigone in the drama either as a representative of any specific position on kinship or as a representative of any specific position within a kinship system. In addition, the book displays "the socially contingent character of 


\section{ANTIGONE'S LINE}

kinship" ${ }^{24}$ despite the fact that this contingency is repeatedly congealed into a static necessity in much critical assessment and theoretical use of the play. Perhaps most importantly, for my present purposes, Butler's analysis presents the socially contingent nature of kinship in the play as a function of actions, and specifically of Antigone's claims aboutand claimings of - her deeds. Her claims about her deeds are themselves likewise deeds that serve to create kinship as a repeated norm. For Butler, though, since the life of a norm requires for its sustenance a repetition whose substance can never be guaranteed to be perfectly replicated, the possibility for the "aberrant repetition of a norm" itself a necessary feature of normativity. If the replication of a norm were guaranteed, were an inevitability, then of course there would be no obeying or disobeying it, no satisfying or failing to satisfy it. Were it impossible to disobey, it would be no norm. The norm has a functionor is what it is-only when it may fail to be met.

My view accords on many points with this performative account of kinship. However, it diverges distinctly from Butler's thought on the matter of when and where the aberrations in kinship occur in this tale. Without wishing to make of Antigone a regressive figure yearning to reinstate a stultifying family form, the account I wish to propose locates the aberration fairly traditionally in Oedipus and Jocasta's offense and considers Antigone's struggle to be an essentially restorative or reparative effort. For Butler, Antigone's "incestuous love of her brother"26 is a "deformation of kinship that she performs." 27 But certainly the play asserts that a deformation has already occurred in her parents' generation of her, and of Polynices, Eteocles and Ismene. This does not mean that she could not enact her own deformation of kinship, of course. However, though it is intense and unyielding, Antigone's love for her brother does not seem to be uniquely or extremely incestuous relative to other loves or professions of love in the play. For Ismene and Haemon also express intense love that could be considered incestuous. Ismene professes her love for Antigone in tones that resemble Antigone's passionate pleas for her brother's priority. Of Polynices, Antigone insists: "I will lie with the one I love and loved by him."28 But Ismene exclaims to Antigone: "What do I care for life, cut off from you?"29 Pleading to die with Antigone, Ismene begs: "Oh no, my sister don't reject me, please, / let me die beside you, consecrating / the dead together." 30 And finally, to Creon, she agonizes: "How can I live alone, without her?"31

For his part, Creon expects, or compels, his son Haemon to 


\section{MARY BETH MADER}

declare his unconditional love for him. Creon presses Haemon: "Are you coming now, raving against your father? / Or do you love me, no matter what I do?" Haemon replies: "Father, I'm your son...you in your wisdom / set my bearing for me--I obey you. / No marriage could ever mean more to me than you...." ${ }^{32}$ Here, Haemon is pushed to profess his father's priority over any eventual wife-let alone over Antigone, his future bride-in his affections. Creon evidences no shame, in fact, in requiring of Haemon exactly what he just deplored in Antigone's defense of her actions: unconditional love. A mere eight pages prior to Creon's demand on Haemon, he is outraged by Antigone's neglect of the condition that Creon believes renders Polynices unmournable, namely, that he made himself an enemy of the city of Thebes.

Perhaps these two instances simply mean that these other characters express or desire intense loves that could be considered incestuous because, after all, they are all afflicted by the incestuous family history and are fatally repeating it. Even if this is so, however, these instances show that Antigone's intense devotion to Polynices is simply not unique in the play. Indeed, that the brother-sister love is readily classed as incestuous by commentators, while the love between sisters or the love between father and son is not, may simply express a preponderant anxiety about specifically heterosexual incest or perhaps reproductive incest. Of course, in some cases, this preponderance may actually be an inability to suspect incestuous potential in such relationships for the reason that same-sex relations have not registered as potentially amorous or erotic at all. But it is not at all clear to me that any of these relations should be considered incestuous by the standards of the play. What is clear is that the reproductive mother-son incest of Jocasta and Oedipus is indeed considered a calamity and an offense.

Butler also argues that Antigone undermines her own pronouncements at several crucial junctures. She adopts Creon's language of sovereignty, deploying it to argue that she must violate the royal law in the interest of serving another law, the unwritten laws of the gods. And yet, Butler argues, this law is no true law, for its hyberbolic particularity means that it applies in only a single instance, to the case of the dead Polynices. Butler construes Antigone's defense speech to mean that "she would risk defying the official edict for no kin but Polyneices." 33 Further, Antigone seeks to express the "radical singularity of her brother" 34 but fails to achieve this singular reference due to the necessary multiplicity of language itself. Her use of the term 'brother' 


\section{ANTIGONE'S LINE}

will always be polyreferential and thus can never isolate her one love in a way that does justice to his uniqueness.

And this despite the fact, for Butler, that brother and father are hardly distinguishable by Antigone. "They are," Butler writes, "after all, already interchangeable for her, and yet her act reinstitutes and reelaborates that interchangeability." ${ }^{35}$ Here, my view is nearly the contrary! It seems correct to say both that Antigone grapples with the question of who exactly are her brothers and that she attempts to refer only to her brother Polynices in defenses of herself. But it seems to me that her efforts are motivated by the aim to disambiguate the multiple statuses of both Polynices and Oedipus and that this aim precedes the staged events of the play. Further, it does not seem to me that Antigone has claimed that she would perform the violative deed for no other kin. Perhaps, finally, an exposition of my understanding of the specific sense of the enigmatic defense speech will help to clarify my partially contrary reading.

\section{Another Answer: "[doom.] It extends to all the kin."36}

Although commentators are correct to stress the irreplaceability of Antigone's brother Polynices, it is an error to consider her reasoning to concern Polynices as $a$ brother, that is, as any brother of any sister. In other words, many readers, like Hegel, extend the argument to apply to all brothers and sisters. This is an error for at least one crucial reason, and it is an error that almost all commentators on the play commit. Within the dramatic logic of the play, Antigone's family form itself is both singular and monstrous. In other words, most commentators have not taken seriously the very dramatic core that gives the play its tragic element: the horror that is the family and the very figures in the play, and especially the fact that the play treats this family as distinctly aberrational. To think that in her defense speech Antigone could be providing a universalizable or generally recommendable rationale for her action, then, is to ignore the exceptional nature of her family form, and for any kinship relations within it. (Perhaps Sophocles' contemporaries did not make this error, and thus perhaps did not experience the same baffled incredulity at her attempted explanation as have subsequent commentators.) When Antigone argues for the irreplaceability of Polynices, then, she should not automatically be taken to be arguing for the irreplaceability to a sister (or even to a sibling) of a brother (or even a sibling). This should not be done because her 


\section{MARY BETH MADER}

family form is singularly aberrant according to the play itself: the incestuous nature of her family is the source of her suffering, as the play makes clear repeatedly.

Accordingly, some readers tend to miss the profundity and meaning of Antigone's "family affection" for her brother. They also tend to ignore the importance of what she might wish not to do. Further, the question of Antigone as agent, what she can do or effect and what she cannot or will not do or effect is one of the play's great issues. This issue takes urgent shape in the following questions: (1) In particular, what exactly is a brother? (2) More generally, how are family or kin relations created and maintained? Antigone is about the establishment, erosion, or re-establishment of a certain type of kin relation and a family constellation that preserves it.

Antigone is not simply honoring her brother because he is her brother, she is making a man be her brother by her treatment of him. Most importantly, she is establishing (or attempting to establish) her brother as only her brother by symbolically refusing a family precedent, namely that of generating one's own sibling. Antigone's devotion to her brother must be understood against the backdrop of her family story. Jocasta is both her mother and her grandmother. That is, Jocasta is the parent of her own child Oedipus and of her own grandchildren; she is both the parent and the grandmother of her own children by Oedipus. Oedipus is both Antigone's father and her brother; she is both his sister and his daughter. Further, taking into account Antigone's relation to Polynices by way of her relations with other family members, Polynices could also be said to be Antigone's uncle or her nephew. By way of Oedipus as Antigone's brother, Polynices is the son of Antigone's brother, which makes him her nephew. But by way of Oedipus as Antigone's father, Polynices is Antigone's uncle, since Polynices is her father's brother. So, she is sister, aunt and niece to Polynices.

In order to understand Antigone's tragic efforts, consider two categories of kin relations: ${ }^{37}$

(1) Relations that one cannot generate oneself. Of these, one cannot "get another" because one cannot get one tout court. According to the vocabulary of the normative form of kinship order from which the Oedipal family has departed, this category includes: father and mother. ${ }^{38}$

(2) Relations that one can generate oneself or help to generate oneself. Of these, one can "get another" in the sense that one plays a causal role in their coming to be. According to that same vocabulary 


\section{ANTIGONE'S LINE}

of the normative form of kinship order from which the Oedipal family has departed, this category includes: child, husband, and wife.

We can understand the question haunting Antigone as: Is 'brother' of the first or the second sort of relation? Is 'brother' in category (1) or (2)? When it is productive of a child, Oedipal incest amounts to putting the sibling relation or the brother relation in category (2). That is, Antigone could "get another" brother, were she to follow in her father's footsteps and generate a brother by him, her parent. ${ }^{39}$ Against the background of Oedipal incest placing the sibling relation in category (2), we can read Antigone's violative deed as a passionate attempt to restore the sibling relation to category (1). Her burial of her brother is the making of a brother as something that "cannot" be made by oneself; it is an attempt to make a "can not" of an "ought not," to impart to a supposed social or moral necessity the strength of an ontological necessity. The point of the play is that we may not assume that this is given, but that brothers are made as brothers-who-are-not-also-uncles by a refusal of the Oedipal type of incest. In a sense then, if this refusal is a making, Antigone's insistence on performing the burial rites for her brother as brother consecrates not just a dead beloved sibling but a certain precarious version of siblinghood or brotherhood itself, and attempts to bring a lost generational order back to the family. It is precisely the precarious status of this generational order that is the source of the deep distress and anguish that fuels Antigone's determined course and the dramatic line of the play.

Given the uniqueness of her family genealogy, then, Antigone cannot be said to be fighting for parental, paternal or maternal filation or right per se. Her action, her violation of Creon's prohibition on burying her dead brother, is essentially both a necessary and an impossible attempt at restoration of her family's skewed genealogy. It is necessary because she must affirm the priority of the genealogically given, of those who were made, and made siblings, by others (than she), in this case, Polynices. Note that she did perform "with my hands" burial rites for her dead brother Eteocles, as well. ${ }^{40}$ In some translations, it is also clear that Antigone has already so honored her parents as well as Eteocles: "All three of you have known my hand in death."41 In addition, in Oedipus at Colonus, a messenger reports that Ismene and Antigone prepared their father for burial: they "bathed him in holy water, decked his body out / in shining linen, the custom for the dead."42

So, given Antigone's family heritage, what can she do to try to restore or create a generational order that is not horrifying? In my 


\section{MARY BETH MADER}

view, she is adamantly affirming — with rites that are supposed to be for family members, and hence, especially mark them as such - family relations created not by her but by other family members. She is desperately trying to ratify these relations-not instituted or created by her-as, precisely, beyond her creation. This is the tragic paradox of having to make someone be a brother-and only a brother-through stressing that a brother is precisely what one ought not, though one can, make. Notice also that Antigone stresses that Polynices is her brother (rather than her nephew or uncle) precisely by stressing that Oedipus is their father (rather than their brother). She is trying to disambiguate the dual status of brother-father in the case of Oedipus and the multiple status of brother-nephew-uncle in the case of Polynices, and of herself as sister-daughter relative to Oedipus and sister-niece-aunt relative to Polynices. She is trying to insist upon one of these positions- - father for Oedipus and brother for Polynices — in an essentially restorative effort, that is, an effort to re-establish a family tree with less horrifying articulations.

The obvious objection to these speculations is that, as Antigone herself says, her parents are both dead, at this point in the tale. But perhaps we need to recall that Antigone interprets her suffering and that of her siblings as stemming from her father's wrongs. ${ }^{43}$ And from this recollection, it is plausible that Antigone would be extremely vigilant about her family's criminal status and about her own potential for offense against the gods of the dead-even well prior to the period presented in the play. If her father's offense is "getting another brother" in part through his own agency, then Antigone could understandably be concerned to efface that offense and to bar its possible recurrence throughout the course of her life, even prior to her father's death. Hence, the elevation of the brother as "that which I cannot get for myself." Granted, here she implies that the only reason she cannot get one is because both of her parents are dead. The obvious interpretation of this is that they (that is, both Oedipus and Jocasta) are required to get her another brother and, being dead, cannot do so. Her insistence on her parents being the unique source of a brother is obviously significant in her task to efface the family crime. And it makes sense that she would be publicly proclaiming her realization of this unique source, in the form of an action known by the city as a whole, the burial of Polynices. ${ }^{44}$ But we can also easily imagine a knowing audience noting, with cruel humor perhaps, that of course, had Antigone's father alone been alive, she could have followed in his footsteps and procured 


\section{ANTIGONE'S LINE}

for herself a brother by her parent.

Imagine, then, that the preoccupation with her confounding kinship precedes the burial prohibition, that awareness of her father's unwitting crime and its issue lays down for her the track of her tragic options. Imagine that well prior to her brothers' deaths by interkilling, the shameful ouroboros in the branches of her family tree keeps her ever vigilant about precisely what acts constitute the family relations in question in her tale. Then consider her claim in the enigmatic passage to be: I cannot get myself another brother. ${ }^{45}$ Yes, the reason she provides is that her parents are required to give her a brother and they are both dead. But the "I cannot" would be the constant, self-addressed, protective mantra whose more insistent sense is: "I must not." And this expression of "cannot-must not" is exactly what contains the unexpressed "law" she stresses but seems never to state explicitly. That law is: getting oneself a brother is the kind of action that one can perform though one must not, unlike getting oneself a husband or a child. In fact, children and husbands are constituted as only children and husbands-within the kinship order Antigone takes to be normative-in part precisely by constituting brothers as only brothers, or siblings as only siblings.

Of course, what a brother is, and what actions constitute a brother as only a brother are strictly tied to the particular kinship order or orders operating in the play. Nowhere do I mean to imply the existence or validity of any universal, trans-temporal or trans-cultural system, rule or order that would govern or express any constant content to the term "brother." Nor would I wish to attempt any kind of translation system for kinship, which is essentially what the work of Levi-Strauss and followers has sought. That is, his approach to the study of kinship is basically one that seeks to devise a formalism into which any distinct kinship order could be translated. As is well known by now, the anthropological equivalent of the linguistic "target language," in such projects, is some dominant Occidental kinship system or other. Rendering the terms of a different kinship order intelligible in one's own terms alone is the solipsistic goal of such approaches. The Hegelian reading of Antigone likewise imposes much too readily Hegel's own assumptions about family relations, gender roles, and customs pertaining to death upon the play.

My attempt has been to remain as close as possible to the elements of kinship as they appear in the play, and not to assume an easy continuity with kinship terms that operate in presently dominant 


\section{MARY BETH MADER}

Occidental kinship regimes. Of course, this is hardly completely achievable since, among other reasons, my use of contemporary English language terms commits me to certain current senses of these, in any case. But if the play continues to tantalize or instruct, this must in part be due to readers' assuming some commonality of experience or conditions between ancient Greek family life and subsequent family life there and elsewhere. My approach does not avoid the risks of that assumption. On a related note, I do not mean to imply either that any coherent single perspective on kinship is evidenced in the play, aside from the fact that no voice in the drama expresses the view that the family crime in play is not a violation.

\section{"No generation can free the next" $"$}

The subject of the play is the liberation of one generation by another. But in a family in which the generational order is, from within the play's own perspective on the matter of kinship, incestuously compressed, generatively overlapping, or relationally congested, the problem of one generation's freeing another is a problem latent in the very facts of human generation itself. That is, when it comes to Antigone's generation, one that is produced in violation of divine law, the effects of such generational violation spread through the very network they create; the poison is delivered throughout the system by and in the creation of the system. Hence, it has a kind of necessary means of propagation; the "curse" of the house of Oedipus is not most importantly the resounding power of a verbal malediction. It is rather the inescapability of existence as a violation, of being as beingwrong, or being-as-should-not-be.

Is it possible by one's living, in one's life, to re-establish or to establish anew a limit when one's very life is only as a violation of that limit? Can Antigone establish a non-incestuous family? Tragically, the only way she can establish a non-incestuous family is by recognizing those family members that she did not bring about and, from within the predominating perspective of the drama, that she ought not bring about. For the incestuous violation in the play is due precisely to not recognizing a progenitor as a progenitor (then recognizing too late), and hence not heeding a law that one ought not do all one can do; in other words, the limit must be imposed, it will not impose itself. The laws and gods of the family prescribe a limit, but the limit must be imposed by human beings, and violation of it in this case actually is the 


\section{ANTIGONE'S LINE}

children of Oedipus, and their suffering. On this view, violating Creon's law should appear in itself to be a negligible offense in comparison with what is at stake in obeying it. ${ }^{47}$ Obeying Creon's law, for Antigone, means not recognizing her parents as parents, which is precisely Oedipus' failure, as well as the source of her very being.

So prior to the tragic conflict of two unyielding wills, in the persons of Antigone and Creon, the deeper tragedy is the ever-ruined, imperfect set of options for restoring a less horrifyingly collapsed lineage. The deeper tragedy, then, is that the only minimal restoration of a cleansed lineage, for Antigone, would go by way of honoring the very parents whose parentage is the ghastly violation. In order not to repeat her parents' offenses, she must affirm them as parents, which status is precisely the origin of their depravity.

Antigone, in a consuming orientation to purification or restoration of her family's debased state, views all possible actions as confined on all sides by actions that are awfully possible yet deadly repetitions of her parents' accursed legacy. Why must she recognize and affirm them as parents, then? With all the weight of what she describes as a life of almost intolerable pain and sorrow pressing upon her, ${ }^{48}$ she is propelled by an overcompensatory vigilance and unconditional drive to fend off any possible repetition or hint of recurrence of the family's generative crime.

Perhaps, then, she endures a feared identification with her father. It is Oedipus' crime, after all, that predominates in the tale as a whole, obviously, and this crime is essentially that of not recognizing both mother and father. For not recognizing his mother, though, he has created his children and their suffering. But Jocasta's crime is different; it is the crime of not recognizing her child, her son. So by symbolically recognizing Polynices as her brother, as not only irreplaceable in general but as irreplaceable by her, Antigone can affirm that her parent's generative power itself is irreplaceable, thus symbolically "avoiding" Oedipus' crime, since he supplanted his father in the couple that was his parents. ${ }^{49} \mathrm{By}$ "irreplaceable by her," I mean that Polynices as a brother is not replaceable by her, in contrast to the roles or relations of husband or child being replaceable by her own efforts. I might be charged with equivocating on the term "recognition" in this discussion, using it both to mean "to pay homage to" and "to identify by recollection." The double sense is not problematic for this reading, however, since I do mean to imply that the first sense includes the second one. So, in the case of Antigone's symbolic "recognition" of her brother as a brother 


\section{MARY BETH MADER}

only "recognition" includes her re-identification of him as the brother Polynices.

Antigone is particularly disturbed by her own understanding of her confused genealogy, and especially by her relation with the hyperrelated Oedipus. It is clear that the entire tragic incestual crimethat is, that such a thing is incestual and criminal, according to the playdepends in fact on the importance of maternal filiation. For if the blood tie went primarily through the father, (as it clearly is legally determined to do at the end of Aeschylus' Oresteia), Antigone's and Oedipus' relations would not be problematically mixed, or would not be maximally so mixed. If paternal filiation were the rule, here, then Antigone and Oedipus, having different fathers, would not be both siblings and in a relation of descent-for they simply would not be siblings. ${ }^{50}$ So, the incestuous nature of Oedipus' procreation depends on the social logic in which parentage is importantly carried by maternity. In this family, the mother legates criminality with her very issue - or at least with the children of her second husband.

\section{Endpoints}

Plainly, despite some important commonalities, the proposed understanding of the enigmatic passage and of the play contrasts with the accounts offered by Lacan and Butler on several points. To return to my discussion of Lacan's account, now we can see why Antigone might be so concerned with those who are "born of the same womb." On the proposed reading, Antigone's emphasis on those who are "born of the same womb" is not simply an emphasis on those who are irreplaceable per se. Yes, plainly, they are ranked more highly than others, but not just any or all others. The crucial comparative others at issue are those others who permissibly may be replaced by her own agency. The question is: why is Antigone willing to die for this distinction between those whom one is permitted to generate and those who one is not permitted to generate? The answer is that violating that distinction was precisely the substance of the family crime. Antigone is willing to die to defend and consecrate the distinction between those who must be other-generated and those who can be self-generated. One tragic outcome of the play is that in her own case she must sacrifice the latter for the former.

It is for these reasons that brother must be ranked over husband and child in the case of this family. And it is a weakness of Lacan's 


\section{ANTIGONE'S LINE}

explanation that it cannot account for the apparent necessity of this difference in treatment. It cannot do so because it does not construe Antigone's distinction properly, as one between the illicitly autogenerated and the licitly heterogenerated.

On the reading proposed here, Butler's charge that Antigone appeals to a law that is no law at all receives no confirmation. For the proposed reading argues that Antigone appeals to a law whose application is not limited to Polynices alone, and hence it is not disqualified from being a law by the paltry scope of its relevance. On this reading, the law would mean that siblings ought to receive special treatment as those whom one can but ought not create oneself. The law is: recognize your parents as they who can generate those who you can, though must not, generate. The crucial causal corollary is: it is precisely by this recognition that such beings as parents, children, and siblings are made as such in this particular kinship order. The law, then, is a form of incest prohibition, or more precisely the establishment of what counts as prohibited relations. Antigone's achingly retrospective affirmation of this law does not succeed in effacing the genealogical violation without eliminating its fruit: herself. The end of the play implies that she cannot undo that violation without undoing herself.

This is partially because of Creon's position on the priority of state and ruler over philous, kin and household. From the play's start, Sophocles presents Creon as the adamant defender of the priority of state and ruler over philous, kin and household. Philous, or friends and close relations, depend for their well-being on a stable, well-ordered state, for Creon; the state makes possible strong and abiding friendships and close family relations. ${ }^{51}$ It is only at the dreadful unraveling of his own close family bonds at the play's end that Creon seems to realize that his iron governance has been no protection for his close relations. In exclamatory self-description, he cries: "Wailing wreck of a man, / whom to look to? Where to lean for support?"52 That cradling ship of state he had earlier invoked is here no solace, no refuge.

In sum, the proposed view agrees with Butler's performative construal of the socially contingent nature of kinship, but takes the iterative character of the kinship norm in this case to permit not Antigone's aberrant deformation of kinship but her essentially reparative effort at re-formation of an unshamed and unashamed family constellation. Note that this restorative effort is not considered by Antigone to be solely her own mission, at first, either. The fact that Antigone initially expects her sister Ismene to share her illicit initiative 


\section{MARY BETH MADER}

shows that on Antigone's view her sister is placed just as well to wish to carry out the burial duties as she is. More importantly, it demonstrates that the play cannot be about the incestuous desire of the individual figure Antigone, at least if the thought of Antigone should be counted in answering the question of her ultimate motivations. Surely, there is no reason to think that she was enjoining her sister to risk death for an incestuous desire they both shared for their ungrieved brother.

The paper has argued that Antigone's aim is to un-double her overwritten kin, even those kin who are dead. How can anyone in her family free or honor the next-or the previous - generation when its generations are barely or tenuously individuated? If the reading sketched here has any plausibility, it indicates that fragile, confected kin relations can be approached by indirection as well as by targeted directness. If "doom extends to all the kin" precisely as the kin, if the helplessness of human beings in such netted bonds as families joins them by their choice and not, then Antigone's election of her brother Polynices as the point at which to pluck at the generational tangle is likewise the choice to release all her kin from their family shame.

Butler is more right than her own claims indicate when she holds that Antigone "remains somewhat unthinkable." ${ }^{33}$ For we must suspect that kinship itself is what is "unthinkable," still, after innumerable and continuing performances of the ancient Greek dramas of family passions. Otherwise how explain the seemingly automatic reversion to various "forms of idealized kinship" 54 that plainly have made the Oedipal family impervious to clear view, and particularly in the case of this enigmatic passage, have obscured the very nature of the horror that that play presents. Indeed, Bernard Knox's remonstration quoted above- " "for there is no closer relationship imaginable than that between the mother and the children of her own body"-should sound like a joke when pronounced about the Oedipal family! Right, "no closer"a little too close, in this case, no? That any one of us could read over the remark in seriousness is a demonstration of the persistent unthinkability of the everyday tangle of kinship.

University of Memphis

\section{Notes}

${ }^{1}$ Oedipus at Colonus in Sophocles: The Tbree Theban Plays, trans. Robert Fagles (New York: Penguin Books, 1984), 296. (Hereafter references to this 


\section{ANTIGONE'S LINE}

translation are abbreviated as "Fagles.") This paper benefited from the talents of: Athena Athanasiou, 'Tina Chanter, Karin DeBoer, Alan Kim, Kyoo Lee, Kelly Oliver, Diane Perpich, Gilberte de Poncheville, Elizabeth Povinelli, and Elena Tzelepis. My thanks to them all. Any infelicities are thanks to my own talents.

${ }^{2}$ Fagles, 105, lines 995-1005. The relevant passage is: "Never, I tell you. / if I had been the mother of children / or if my husband died, exposed and rotting - / I'd never have taken this ordeal upon myself, / never defied our people's will. What law, / you ask, do I satisfy with what I say? / A husband dead, there might have been another. / A child by another too, if I had lost the first. / But mother and father both lost in the halls of Death, / no brother could ever spring to light again. / For this law alone I held you first in honor." For alternate translations, see note 45 below.

${ }^{3}$ Aristotle, The Rbetoric and Poetics of Aristotle, trans. W. Rhys Roberts (New York: The Modern Library, 1984), 209 (Book III, Chapter 16, 1.1417a 25-35): "Where any detail may appear incredible, then add the cause of it; of this Sophocles provides an example in Antigone, where Antigone says she had cared more for her brother than for husband or children, since if the latter perished they might be replaced, But since my father and mother in their graves / Lie dead, no brother can be born to me."

${ }^{4}$ Fagles, 47.

${ }^{5}$ Dudley Fitts and Robert Fitzgerald excise the passage, regarding it as "dismal stuff:" "Antigonê is made to interrupt her lamentation by a series of limping verses whose sense is as discordant as their sound." Sophocles: The Oedipus Cycle: An English Version, Ed. Dudley Fitts and Robert Fitzgerald (New York and London: Harcourt Brace Jovanovich, 1977), 240.

${ }^{6}$ Fagles, 46-47.

${ }^{7}$ Therese Ahearn Augst, "Difference Becomes Antigone: Hölderlin and the Ethics of Translation," seminar 38:2 (May 2002): 101.

${ }^{8}$ Fagles, 45: "Antigone turns her back on the claims of blood relationship and the nether gods in one sentence: three lines in Greek, no more....They are certainly a total repudiation of her proud claim that she acted as the champion of the unwritten laws and the infernal gods, for, as she herself told Creon, those laws and those gods have no preferences, they long "for the same rites for all."'

${ }^{9}$ Fagles, 45-6.

${ }^{10}$ Fagles, 64, 1. 90.

${ }^{11}$ Fagles, 44 and 85.

${ }^{12}$ Fagles, 49.

${ }^{13}$ Fagles, 51.

${ }^{14}$ Martha Nussbaum, The Fragility of Goodness (Cambridge: Cambridge University Press, 1986), 440, n.44. George Steiner, in Antigones (New Haven: Yale University Press, 1996), advances this view as well: "Antigone, who has 


\section{MARY BETH MADER}

denied Eros, who has interposed a sterile purity of moral will..." (273).

${ }^{15}$ See Tina Chanter, Ethics of Eros: Irigaray's Rewriting of the Philosophers (New York: Routledge, 1995), 290, n. 39.

${ }^{16}$ Jacques Lacan, "L'Essence de la tragédie," in Le Séminaire, Livre VII: L'Etbique de la psychanalyse (Paris: Editions du Seuil, 1986), 297-8. English translation: "The Essence of 'Tragedy: A Commentary on Sophocles' Antigone," in The Ethics of Psychoanalysis, The Seminar of Jacques Lacan, Book VII, ed. JacquesAlain Miller, trans. Dennis Porter (New York and London: Norton, 1992). Translations in the text are mine.

of the gods"

${ }^{17}$ Fagles, 82. The phrase Lacan discusses is: "the unwritten laws. . .

${ }^{18}$ Fagles, 105-6: "What law, you ask, do I satisfy with what I say?" And: "For this law alone I held you first in honor."

${ }^{19}$ Lacan, Séminaire, Livre VII, 324-5.

${ }^{20}$ Lacan, Séminaire, Livre VII, 324.

${ }^{21}$ Lacan, Séminaire, Livre VII, 325.

${ }^{22}$ See Fagles, 395, n. 12 and 397, n. 213 for this Greek term.

${ }^{23}$ Judith Butler, Antigone's Claim: Kinship Between Life and Death (New

York: Columbia University Press, 2000).

${ }^{24}$ Butler, Antigone's Claim, 6.

${ }^{25}$ Butler, Antigone's Claim, 58.

${ }^{26}$ Butler, Antigone's Claim, 6.

${ }^{27}$ Butler, Antigone's Claim, 28.

${ }^{28}$ Fagles, 63.

${ }^{29}$ Fagles, 87.

${ }^{30}$ Fagles, 87.

${ }^{31}$ Fagles, 89.

${ }^{32}$ Fagles, 93.

${ }^{33}$ Butler, Antigone's Claim, 60.

${ }^{34}$ Butler, Antigone's Claim, 77.

${ }^{35}$ Butler, Antigone's Claim, 61.

${ }^{36}$ Sophocles, The Complete Greek Tragedies: Sopbocles I: Antigone, ed. David Grene and Richmond Lattimore (New York: Washington Square Press, 1967), 184, 1.586. Henceforth abbreviated as GL

${ }^{37}$ Note that the distinction between these two categories is not that between alliance and generation, for the child relation is included in the same category as the husband and wife relations.

${ }^{38}$ Plainly, I am leaving aside the cases of children selecting parents through adoption and analogous means.

${ }^{39}$ Incidentally, it seems that because of Oedipus' incest with Jocasta, incest between Antigone and Oedipus would be father-daughter incest and/ or brother-sister incest.

${ }^{40}$ Fagles, 105. 


\section{ANTIGONE'S LINE}

${ }^{41} \mathrm{GL}, 194,1.900$.

${ }^{42}$ Fagles, 379, 1. 1816-17; GL, 152, 1.1602-3. Here, however, Oedipus is not dead and his grave will be kept secret from his daughters / sisters.

${ }^{43}$ Antigone's first words include these: "Dear sister, dear Ismene, / how many griefs our father Oedipus handed down!" (Fagles, 59,1.2). Another rendering of the line is: 'You would think that we had already suffered enough / For the curse on Oedipus." Sophocles, The Oedipus Cycle, trans. Dudley Fitts and Robert Fitzgerald, (New York: Harcourt Brace Jovanovich, 1977), 185.

${ }^{44}$ Indeed, note that although the chorus seems not to understand the source of her inflexible drive to bury her brother, and at best is highly skeptical about the deed, this is not true of the city itself, according to Haemon's report to Creon. Haemon says: "But it's for me to catch the murmurs in the dark, / the way the city mourns for this young girl. / No woman,' they say, 'ever deserved death less, / and such a brutal death for such a glorious action. / She, with her own dear brother lying in his blood - / she couldn't bear to leave him dead, unburied, / food for the wild dogs or wheeling vultures. / Death? She deserves a glowing crown of gold!"' (Fagles, 95). He battles on: “ Haemon: I'd never suggest that you admire treason. Creon: Oh? — / isn't that just the sickness that's attacked her? Haemon: 'The whole city of 'Thebes denies it, to a man" (Fagles, 97). In addition, Antigone claims that the chorus members are cowed by Creon and that they meekly go along with his view, although they privately oppose it: "These citizens here would all agree, / they would praise me too / if their lips weren't locked in fear" (Fagles, 84).

${ }^{45} \mathrm{I}$ include two other translations of the passage. "O but I would not have done the forbidden thing / For any husband or for any son. / For why? I could have had another husband / And by him other sons, if one were lost; / But, father and mother lost, where would I get / another brother?" Sophocles: The Theban Plays, trans. E. F. Watling (New York: Penguin Books, 1981), 150. Fitts and Fitzgerald also provide the Oxford Translation: "For neither, though I had been the mother of children, nor though my husband dying, had mouldered away, would I have undertaken this toil against the will of the citizens. On account of what law do I say this? There would have been another husband for me if the first died, and if I lost my child there would have been another from another man! But my father and my mother being laid in the grave, it is impossible a brother should ever be born to me" Sophocles: The Oedipus Cycle, trans. Dudley Fitts and Robert Fitzgerald, (New York: Harcourt Brace Jovanovich, 1977), 240.

${ }^{46}$ GL, 184, 1. 594.

${ }^{47}$ Indeed, Antigone says as much: "So for me, at least, to meet this doom of yours / is precious little pain. But if I had allowed / my own mother's son to rot, an unburied corpse - / that would have been an agony! This is nothing" (Fagles, 82).

${ }^{48}$ See Fagles, 59, 1.6-9; 82, 1.516-18. 


\section{MARY BETH MADER}

${ }^{49}$ Antigone does not appear to be as motivated to avoid her mother's crime as she is to avoid her father's. For the lines in her counterfactual imaginings that have so disturbed and surprised readers are an exact description of her mother's life. She says: "A husband dead, there might have been another. / A child by another too, if I had lost the first." Jocasta's first husband Laius was killed by Oedipus, who himself became "another" husband. Oedipus, Jocasta's first child, was lost to her by her own abandonment of him. And, of course, she had four more children by Oedipus. Despite this potential parallel, then, Antigone's driving anxiety seems focused upon the danger of not recognizing one's parent, rather than on Jocasta's crime of not recognizing one's child. The play as a whole, though, plays down Jocasta's crime in contrast to Oedipus'.

${ }^{50}$ Plainly, I ignore the question of the status of full- or half-siblings.

${ }^{51}$ Creon proclaims: "Our country is our safety. / Only while she voyages true on course/can we establish friendships, truer than blood itself. / Such are my standards." (Fagles, 68)

${ }^{52}$ Fagles, 127.

${ }^{53}$ Butler, Antigone's Claim, 22.

${ }^{54}$ Butler, Antigone's Claim, 28. 